\title{
ANALISIS SEGMENTASI PASAR "LORJUK" (Solen grensalis) DI KABUPATEN PAMEKASAN
}

\author{
Endang Tri Wahyurini, S.Pi.,M.Agr \\ Dosen Program Studi Agribisnis Perikanan \\ Fakultas Pertanian Universitas Islam Madura
}

\begin{abstract}
ABSTRAK
Penelitian ini dimaksudkan untuk mengetahui segmentasi dan positioning dari produk "lorjuk". Keragaan "lorjuk" masih di daerah Pamekasan masih memiliki potensi yang menjanjikan. Dalam penelitian ini, penentuan responden dengan metode purposive sampling atau metode penentuan responden secara sengaja yaitu para produsen "lorjuk" yaitu pencari, pengolah, pengepul dan penjual "lorjuk" serta konsumen yang mengkonsumsi "lorjuk".Penelitian ini dilakukan selama tiga bulan di dua wilayah Kecamatan yaitu Kecamatan Pademawu dan Kecamatan Galis Kabupaten Pamekasan. Data yang sudah terkumpul dianalisis menggunakan analisis cluster.Adapun hasil kesimpulan yang diperoleh adalah sebagai berikut segmentasi "lorjuk" menurut sudut pandang produsen adalah bahwa "lorjuk" merupakan sumber penghasilan yang masih diminati oleh konsumen- konsumen tertentu. Produsen harus melakukan difersifikasi agar produk "lorjuk" yang dijual bisa bertahan di pasaran. Sedangkan "lorjuk" menurut sudut pandang konsumen adalah bahwa "lorjuk" Pembahasan tentang cluster 1 menunjukkan bahwa responden yang memilih atribut rasa enak dan gurih, protein tinggi dan merupakan makanan sehat sebanyak 33,3\%, sedangkan yang memilih atribut suka seafood, prestise dan image yang bagus sebanyak $23,3 \%$ dan yang memilih atribut bisa dibuat camilan, dibuat oleh-oleh dan di buat suguhan tamu sebanyak 43,3\%. Hal ini menunjukkan bahwa segmentasi pasar "lorjuk" untuk konsumen lebih didominasi karena alasan sebagai makanan camilan, untuk oleh-oleh dan untuk suguhan tamu dirumah yaitu sebesar $43,3 \%$.
\end{abstract}

Kata kunci : Analisis, Segmentasi pasar, Lorjuk”

\section{PENDAHULUAN}

\section{Latar Belakang}

Wilayah pesisir dan lautan Indonesia yang kaya dan beragam sumber daya alamnya telah dimanfaatkan oleh bangsa Indonesai sebagai salah satu sumber makanan utama, khususnya protein hewani. Namun potensi perikanan laut di Indonesia yang sangat besar dan beraneka ragam itu belum dimanfaatkan secara maksimal. Potensi lestari sumber daya ikan laut Indonesia mencapai sekitar 6,26 juta ton per tahun atau $7 \%$ dari total potensi lestari sumber daya ikan laut dunia dengan tingkat pemanfaatan oleh nelayan mencapai 5,6 juta ton ( Dahuri, et al, 2006).

Kerang-kerangan adalah komoditas perikanan yang cukup diminati oleh konsumen. Salah satu kerang-kerangan yang cukup populer di masyarakat Indonesia yaitu kerang pisau atau 
"lorjuk" (Solen spp). "Lorjuk" merupakan istilah lain dari kerang pisau yang digunakan oleh sebagian besar masyarakat Jawa Timur. Beberapa jenis makanan dan snack berbahan baku "lorjuk" yang telah dikreasikan oleh masyarakat antara lain kacang goreng "lorjuk", soto lorjuk, petis lorjuk, bothok lorjuk dan rengginang lorjuk. Hasil perhitungan Survei Sensus Ekonomi Nasional (SUSENAS) 2009 menunjukkan bahwa penyerapan pasar untuk komoditas kerang/siput di tingkat rumah tangga mencapai 25.450 ton dengan konsumsi rata-rata $0,11 \mathrm{~kg} / \mathrm{kapita}$ (Ditjen PPHP 2010).

Maraknya isu keamanan pangan terhadap komoditi kerang/siput diduga mempengaruhi tingkat konsumsi komoditi ini. Selama kurun waktu empat tahun terakhir, tercatat konsumsi kerang/siput secara nasional mengalami penurunan yang cukup signifikan. Kerang/siput merupakan salah satu jenis ikan yang tercantum dalam daftar Survei Sensus Ekonomi Nasional (SUSENAS). Melalui data SUSENAS, dapat dilakukan penghitungan konsumsi pangan, termasuk diantaranya kelompok pangan dari ikan. Jumlah ikan yang tercakup dalam data SUSENAS berjumlah 32 jenis. Data SUSENAS mampu menggambarkan konsumsi pangan secara riil yang dilakukan oleh rumahtangga dengan pendekatan pengeluaran pangan.Hasil perhitungan $\quad$ SUSENAS 2009 menunjukkan bahwa penyerapan pasar untuk komoditas kerang/siput di tingkat rumah tangga mencapai 25.450 ton dengan konsumsi rata-rata $0,11 \mathrm{~kg} / \mathrm{kapita}$. Selama periode tahun 2006 - 2009, tingkat konsumsi tahun 2009 merupakan tingkat konsumsi yang terendah. Sedangkan tahun 2007 merupakan tingkat konsumsi kerang/siput tertinggi yaitu mencapai 0,25 kg/kapita. Dari perkembangan tingkat konsumsi tersebut, rata-rata pertumbuhan untuk konsumsi kerang/siput adalah 16,06\%. Anonymous,2010)

$$
\text { Kemungkinan besar "lorjuk" }
$$
menjadi populer karena diambil dari nama daerah kerang pisau itu sendiri yaitu "Lorjuk". "Lorjuk" juga banyak ditemukan di daerah Pantai Kenjeran Surabaya, Perairan Kwanyar Sidoarjo dan Perairan Madura (Anonymous, 2011).

Dalam Anonymous

(2010) "Lorjuk" (Solen vaginalis) adalah salah satu jenis kekerangan ( Pelecypoda ) yang mempunyai nilai ekonomis tinggi. "Lorjuk" merupakan salah satu komoditas perikanan yang memiliki keunikan tersendiri. "Lorjuk" dapat ditemukan dipinggir pantai, namun tidak setiap pantai dapat ditemukan "lorjuk", hanya daerah-daerah tertentu saja. Salah satunya adalah Pamekasan. 
"Lorjuk" merupakan salah satu produk agribisnis yang dikonsumsi sebagai makanan ringan, dan juga sebagai campuran makanan ringan lain seperti rengginang dan kacang goreng. Meskipun harganya mahal "lorjuk" banyak digemari oleh masyarakat, bahkan sering dijadikan oleh-oleh khas Pamekasan. Penjualan "lorjuk" di toko ataupun supermarket cukup lambat, hal ini karena selain harganya yang sangat mahal juga tidak semua orang menyukai dan mampu membeli "lorjuk" tersebut. Kondisi ini menunjukkan bahwa ternyata komoditas "lorjuk" memiliki nilai ekonomis yang tinggi dan menjadi komoditas unggulan yang unik dan khas bagi Pamekasan, namun ironisnya usaha ini masih belum mendapatkan perhatian khusus dari Dinas Perikanan setempat. Hal ini terbukti dari minimnya informasi dan data formal mengenai usaha "lorjuk" ini.

\section{Rumusan Masalah}

Permasalahan dalam penelitian ini adalah bagaimana segmentasi pasar "lorjuk" sebagai komoditas unggulan di Kabupaten Pamekasan

\section{Tujuan}

Dalam penelitian ini memiliki
tujuan untuk membahas mengenai
segmentasi pasar "Lorjuk" di Kabupaten
Pamekasan

\section{KERANGKA PEMIKIRAN}

Suatu model perencanaan sangat diperlukan sebagai pedoman dan acuan pengembangan kegiatan dimasa depan. Pengembangan agribisnis "lorjuk" perlu mendapatkan perhatian khusus karena "lorjuk" merupakan salah satu komoditas perikanan yang memiliki nilai ekonomi tinggi. "Lorjuk" banyak terdapat di sepanjang pantai wilayah Pamekasan dan merupakan sumberdaya lokal unggulan. Hal ini karena"lorjuk" memiliki rasa dan bentuk yang unik dan khas. Proses memperoleh atau mencarinya juga unik karena "lorjuk" diikuti jejaknya, kemudian harus menggali tanah terlebih dahulu selain itu keberadaannya bersifat musiman. Jika air pasang maka tidak bisa mencari "lorjuk". Oleh karena itu harga "lorjuk" ini menjadi sangat mahal. Tidak semua orang mau mengkonsumsi "lorjuk" demikian pula tidak seluruh lapisan masyarakat mampu membelinya.

Melihat kondisi tersebut maka perlu adanya analisis pasar khususnya segmentasi terhadap komoditas "lorjuk" ini. Agar produsen bisa menentukan konsumen mana yang akan dituju, sehingga keuntungan dapat diperoleh secara optimum. Selain itu komoditas "lorjuk" akan bisa semakin berkembang dan maju. Sedangkan dari sisi konsumen akan mampu memenuhi keinginan dan kebutuhan mereka, sehingga kepuasan 
akan diperolehnya. Begitupun preferensi konsumen terhadap "lorjuk " ini semakin jelas. Dan pada akhirnya daya beli konsumenpun bisa meningkat.

\section{METODE PENELITIAN}

\section{Jenis Penelitian}

Dalam penelitian ini menggunakan penelitian deskriptif analistis atau penelitian Eksploratif. Penelitian eksploratif merupakan jenis penelitian yang paling sesuai untuk situasi dimana tujuan penelitian bersifat umum dan data yang dibutuhkan belum jelas. Penelitian eksploratif bertujuan untuk mengembangkan pengetahuan atau dugaan yang sifatnya masih baru dan untuk memberikan arahan bagi penelitian selanjutnya. Penelitian eksploratif sangat bermanfaat ketika peneliti menginginkan pemahaman situasi yang lebih baik dan mengidentifikasikan alternative keputusan.(Mudrajad, 2003)

\section{Waktu dan Tempat Penelitian}

Penelitian ini dilaksanakan selama lima bulan berturut-turut yaitu mulai bulan Januari sampai Mei 2013.

Penentuan lokasi secara sengaja (purposive) dilakukan di Kabupaten Pamekasan dengan pertimbangan bahwa Kabupaten Pamekasan merupakan salah satu daerah penghasil "lorjuk" terbanyak di Pulau Madura.

\section{Teknik Pengumpulan Data}

Untuk memperoleh data, baik data primer maupun data sekunder dilakukan dengan cara :

a. Wawancara

Metode ini dilakukan untuk memperoleh data primer dengan melakukan wawancara secara langsung kepada responden produsen dan konsumen "lorjuk", dengan menggunakan daftar pertanyaan yang telah tersusun. Pengumpulan data dilakukan dengan cara survei dan pengamatan langsung di lapangan sambil melakukan wawancara dengan responden yang telah ditentukan.

b. Observasi

Metode ini dilakukan untuk memperoleh data pendahuluan mengenai keadaan daerah yang akan diteliti dengan melakukan survei langsung ke lokasi penelitian

c. Angket adalah teknik pengumpulan data dengan menyebar kuisioner kepada pencari, pengepul, pengolah, "lorjuk" yang secara sengaja ditemui di lokasi penelitian, toko - toko penjual “ lorjuk" ( Toko Camilan Madura) serta konsumen di wilayah Kabupaten Pamekasan.

d. Studi Kepustakaan

Yaitu dengan cara mencari literature yang relevan mengenai agribisnis 
"lorjuk" serta pemasarannya.

Menurut Jonathan (2006) tujuan

utama melakukan studi literatur

adalah Menemukan variable-

variabel yang akan diteliti,

membedakan hal-hal yang sudah

dilakukan dan menentukan hal-hal

yang perlu dilakukan, melakukan

sintesa dan memperoleh perspektif

baru dan menentukan makna dan

hubungan antar variabel

\section{Teknik Penentuan Populasi dan Responden}

Populasi dalam penelitian ini adalah para nelayan di daerah sentral penghasil "lorjuk" yang ada di Kabupaten Pamekasan yang terdiri dari 2 wilayah kecamatan yaitu Kecamatan Galis dan Kecamatan Pademawu. Penentuan lokasi sampling diambil secara sengaja (purposive) yaitu di 2 wilayah kecamatan tersebut dan respondennya adalah pencari "lorjuk", pengepul dan pengolah "lorjuk" (produsen), toko penjual "lorjuk". Untuk pencari "lorjuk" berjumlah masing-masing 10 orang sedangkan untuk pengepul dan pengolah "lorjuk" tiap kecamatan diambil 3 responden sedangkan untuk "toko penjual "lorjuk" diambil 3. Sedangkan untuk pembeli "lorjuk" (konsumen "lorjuk") berjumlah 10 orang.

Pada penelitian ini pemilihan sumber data secara judgement sampling atau dengan sengaja kepada produsen pengolah "lorjuk" dan konsumen "lorjuk" dengan pertimbangan bahwa para responden dapat memberikan data dan informasi yang berhubungan dengan penelitian ini.

\section{Analisis Data}

Untuk menjawab tujuan pertama yaitu dengan analisis deskriptif kualitatif, yang bertujuan untuk mendapatkan gambaran yang benar mengenai suatu obyek dan menguji kebenaran dari suatu pendapat serta membandingan keadaan yang ada di lapangan dengan teori atau peraturan yang sesuai literatur atau pedoman yang digunakan. Menurut Damaijati (2003) analisis deskriptif yaitu analisis data berdasarkan teori atau konsep yang bersifat umum diapikasikan untuk menjelaskan tentang seperangkat data atau menunjukkan komparasi atau hubungan seperangkat data dengan seperangkat data yang lain. Data yang diperoleh dari hasil wawancara, isian kuesioner dan tinjauan langsung ke lapangan. Data yang dianalisis disajikan dalam bentuk Tabel. Bilson (2004) menyatakan bahwa penelitian kualitatif akan memperoleh data kualitatif seperti kata-kata, narasi, gambar dan rekaman audio dan visual.

Pengolahan data tersebut dilakukan dengan memilah-milah satuan informasi ke dalam kategori-kategori yang sama untuk memudahkan penyusunan 
deskripsi temuan studi. Selanjutnya data yang telah berhasil diolah dan ditampilkan ke dalam bentuk tabel-tabel frekuensi dipakai sebagai alat bantu analisis dan interprestasi, guna menjawab semua pertanyaan dalam penelitian ini.Hasil analisis tersebut juga dipakai sebagai dasar penarikan kesimpulan untuk penelitian ini.

Untuk menjawab tujuan kedua yaitu untuk menganalisis segmentasi pasar "lorjuk" menggunakan cluster analysis yang digunakan untuk mengelompokkam karakteristik responden berdasarkan berdasarkan pendekatan demografi (jenis kelamin, usia, pendidikan, penghasilan dan profesi), perilaku konsumen (manfaat, status dan tingkat pemakaian, kesiapan pembeli, sikap terhadap produk, kejadian dan manfaat yang diinginkan konsumen dan psikografi (aktivitas, minat dan opini). Ada tiga tahap yang harus dilakukan dalam segmentasi pasar Kotler (2003) dalam Ouuch (2011) yaitu :

1. Tahap Survei

Tahap survey merupakan tahap melakukan eksplorasi baik melalui focus group discussion atau dengan wawancara terhadap beberapa kelompok konsumen untuk memperoleh keterangan mengenai tema penelitian.

\section{Tahap Analisis}

Tahap analisis merupakan tahap analisis terhadap informasi yang telah diperoleh melalui survei. Analisis dapat dilakukan dengan menerapkan analisis faktor untuk menelaah variabel-variabel mana yang berkorelasi tinggi kemudian menerapkan analisis cluster untuk menciptakan atau mengetahui kelompok-kelompok pasar yang secara signifikan memiliki perbedaan karakteristik.

\section{Tahap Profil}

Tahap profil merupakan tahap untuk mengidentifikasi profil masing-masing cluster yang terbentuk. Dengan ini akan teridentifikasi perbedaan masingmasing cluster berdasarkan sikap dan perilaku, demografi, psikografi, manfaat atau value yang diharapkan dari sebuah program, kemudian masing-masing cluster diberi nama berdasarkan karakteristik yang menonjol. Fanggidae (2006) dalam Ouuch (2011)

Dalam menetapkan dasar segmentasi Kotler (2003) dalam Dewi dan Safrizal (2008) menyatakan bahwa ada dua cara yang dapat dilakukan yaitu pertama consumen characteristic (karakteristik konsumen) yang merupakan variable utama dalam segmentasi yang terdiri dari : 
1. Segmentasi Geografis

2. Segmentasi Demografis

3. Segmentasi Psikografis

Kotler, Browen dan Makens ( 2002

) dalam Anonymous (2010) menyatakan agar segmentasi pasar atau pengelompokkan pasar dapat berjalan dengan efektif maka harus memenuhi syarat-syarat pengelompokkan pasar sebagai berikut :

1. Measurability, yaitu ciri-ciri atau sifat tertentu pembeli harus dapat diukur atau dapat didekati.

2. Accessibility, yaitu suatu keadaan dimana perusahaan dapat secara efektif memusatkan (mengarahkan) usaha pemasarannya pada segmen yang telah dipilih.

3. Substantiability, yaitu segmen pasar harus cukup besar atau cukup menguntungkan untuk dapat dipertimbangkan program-program pemasarannya.

\section{HASIL DAN PEMBAHASAN}

\section{Keadaan \\ Umum Kabupaten \\ Pamekasan}

Kabupaten Pamekasan merupakan salah satu daerah terluas di Pulau Madura dan mempunyai wilayah pesisir yang luas. Daerah pesisir Pamekasan memiliki karakteristik yaitu adanya fenomena dimana pada lokasi-lokasi dekat pantai, dengan kedalaman sumur yang relatif rendah tetapi masih memiliki kualitas air tawar yang sangat baik dan dipergunakan masyarakat untuk konsumsi sehari-hari.

Secara geografis Pamekasan merupakan bagian dari wilayah propinsi Jawa Timur yang terletak di sebelah timur Pulau Jawa. Pamekasan adalah salah satu Kabupaten di kawasan Pulau Madura yang memiliki luas $729.30 \mathrm{~km} 2$, tepatnya pada koordinat $6^{\circ} 51-7^{\circ} 31$ LS dan $113^{\circ} 19$ $113^{\circ} 58$ BT. Secara demografis, berdasarkan data BPS (2012) jumlah penduduk Pamekasan sebanyak 795.918 jiwa. Dengan kepadatan penduduk per km2 cukup bervariatif. Secara administrative Kabupaten Pamekasan terdiri dari 13 Kecamatan dan 189 Desa/Kelurahan (BAPPEDA Pamekasan, 2012).

Sedangkan dari sisi geografis sebelah Utara dibatasi oleh Laut Jawa, untuk batas Selatan terdapat Selat Madura, di sebelah Barat bersebelahan dengan Kabupaten Sampang dan bagian Timur berbatasan dengan Kabupaten Sumenep. Dataran tertinggi di Kabupaten Pamekasan mencapai 350 meter dari permukaan laut dan yang terrendah berada di Kecamatan Galis yaitu setinggi 6 meter dari permukaan laut. (Anonymous, 2012)

Kabupaten Pamekasan terdiri atas 13 kecamatan yang dibagi lagi atas 178 desa dan 11 kelurahan. Dari 13 kecamatan yang ada di Kabupaten Pamekasan, yang 
memiliki potensi sumberdaya perikanan baik perikanan darat maupun laut adalah sebanyak 12 kecamatan atau 92,3\%. (Anonymous, 2012)

Berdasarkan data Badan Pusat

Statistik Kabupaten Pamekasan 2012 menunjukkan potensi sumberdaya perikanan di Kabupaten Pamekasan berasal dari usaha perikanan yang berbeda-beda sesuai dengan karakteristik wilayahnya. Usaha perikanan yang dilakukan umumnya adalah dari usaha penangkapan di laut maupun perairan umum dan dari usaha budidaya baik ditambak air payau maupun kolam. Produksi penangkapan ikan di laut Kabupaten Pamekasan tahun 2011 mencapai $20.434,8$ Ton. Sedangkan untuk budidaya tambak mencapai 370,1 Ton dan budidaya kolam 132,4 Ton.

Anonymous,2012)

Penelitian dilakukan di daerah yang berhubungan dengan komoditas perikanan yaitu usaha "lorjuk". Kecamatan Pademawu dan Galis seperti yang terlihat pada Gambar 1.1 adalah dua wilayah yang dipilih sebagai lokasi dalam Tesis ini. (Sumber: BAPPEDA Pamekasan, 2012)

\section{Deskripsi Umum Lokasi Penelitian}

\section{Kecamatan Pademawu}

Kecamatan Pademawu merupakan salah satu dari 13 kecamatan yang terdapat di Kabupaten Pamekasan, Madura. Luas Kecamatan Pademawu mencapai 7.189
Ha. . Kecamatan Pademawu memiliki beberapa kawasan pantai.

Di Kecamatan Pademawu ada beberapa desa yang memiliki potensi dalam bidang perikanan terutama untuk komoditas "lorjuk". Di beberapa Desa tersebut dapat ditemui para produsen "lorjuk", yaitu para pencari, pengepul dan pengolah "lorjuk" mereka tinggal di Desa Pademawu Timur dan Desa Tanjung. Namun yang lebih mendominasi adalah Desa Pademawu Timur, sehingga dalam penelitian ini lebih difokuskan di Desa Pademawu Timur.

\section{Desa Pademawu Timur}

Desa Pademawu Timur Kecamatan Pademawu merupakan salah satu dari 22 desa yang terdapat di Kecamatan Pademawu. Secara geografis posisi ketinggian tanah dari permukaan lautnya adalah 8 meter. Curah hujan mencapai 117,7 mml. Suhu udara rata-rata mencapai 37,5 ${ }^{\circ}$ C.Desa Pademawu Timur yang terletak diKecamatan Pademawu berjarak $\pm 10 \mathrm{Km}$ arah tenggara dari Kota Pamekasan dengan kondisi jalan aspal. Untuk sampai ketempat penelitian tersebut, bisa dapat ditempuh dengan sarana transportasi mobil angkutan umum atau ojek sekitar satu jam dari terminal Pamekasan. Luas wilayah Desa Pademawu Timur mencapai 726.015 $\mathrm{M}^{2}$ ( 7,26 Ha). Wilayah tersebut adalah wilayah pesisir yang sangat kental dalam sosial kapitalnya. 
Di Desa Pademawu Timur Kecamtan Pademawu ini terdapat empat Dusun yang penduduknya bekerja sebagai pencari dan pencari "lorjuk", yaitu Dusun Mangunan, Dusun Sawahan, Dusun Mungging Barat dan Mungging Timur. Di Dusun tersebut para istri nelayan bekerja mencari "lorjuk". (Hasil wawancara langsung dengan Kepala Desa Pademawu Timur pada Tanggal 07 Mei 2013)

\section{Kecamatan Galis}

Kecamatan Galis Kabupaten Pamekasan merupakan salah satu dari 13 kecamatan yang terdapat di Kabupaten Pamekasan, Madura. Luas Kecamatan Galis mencapai 3.186 Ha. Kecamatan Galis Kabupaten Pamekasan yang daerah sebelah Timur berbatasan langsung dengan Selat Madura maka mayoritas penduduk di sekitar daerah pesisir tersebut banyak yang menjadi nelayan maupun petani garam. Wilayah pesisir di Kecamatan Galis kondisi penduduknya cukup baik hal ini terlihat dari aktifitas mereka yang cukup dinamis. Banyak kegiatan ekonomi yang mereka lakukan sehingga hampir tidak ada penduduk yang menganggur. Beberapa usaha dalam bidang perikanan yang bisa ditemukan di Kecamatan Galis ini adalah pengolahan krupuk, pengupasan kulit rajungan, pemindangan dan pengolahan "lorjuk". Beberapa Desa yang memiliki potensi perikanan terutama "lorjuk" adalah Desa Polagan dan Desa
Galis. Namun yang mendominasi untuk usaha "lorjuk" terdapat di Desa Polagan. Untuk itu penelitian ini lebih difokuskan pada Desa Polagan Kecamatan Galis.

\section{Desa Polagan}

Desa Polagan merupakan salah satu dari 10 desa yang terdapat di Kecamatan Galis. Secara geografis posisi ketinggian tanah dari permukaan lautnya adalah 8 meter. Curah hujan mencapai $200 \mathrm{~mm} / \mathrm{th}$. Tinggi tempat dari permukaan laut adalah 11 m.(Anonymous,2012)

Luas wilayah Desa Polagan adalah 519. $642 \mathrm{M}^{2}$ atau $5.19 \mathrm{Ha}$ dengan batas wilayah Desa yaitu : sebelah Utara Desa Panaguan, sebelah Selatan Desa Lembung - Galis, sebelah Barat berbatasan dengan Desa Bulay dan untuk bagian Timur berbatasan langsung dengan Selat Madura. Jumlah penduduk Tahun 2012 Desa Polagan sebanyak pada sebanyak 5.452 jiwa yang terdiri dari 2.771 orang laki-laki dan 2681 orang perempuan. Dengan jumlah kepala keluarga 1.679 KK. Mayoritas penduduknya memiliki mata pencaharian sebagai nelayan yaitu sebanyak 502 orang.

Beberapa wilayah desa di Pamekasan merupakan daerah pesisir. Dua diantaranya adalah Desa Polagan di Kecamatan Galis dan Desa Tanjung di Kecamatan Pademawu. Di Kedua desa tersebut memiliki potensi wilayah yang berupa hasil pantai yaitu "lorjuk". Sebagai 
komoditas perikanan yang memiliki nilai ekonomis tinggi maka "lorjuk" menjadi salah satu tujuan penangkapan.

Tidak semua wilayah pantai bisa ditemukan komoditas "lorjuk", wilayah ini merupakan pusat penghasil "lorjuk" terbesar di Pamekasan. Meskipun dari segi produktifitas masih rendah, sehingga belum mendapatkan perhatian khusus dari pemerintah daerah setempat. Hal ini terbukti belum adanya pendataan dari desa maupun dari penyuluh perikanan. Sehingga data produksi lorjuk belum bisa diperoleh secara pasti.

\section{Karakteristik Responden}

Produsen

Responden yang digunakan dalam penelitian ini adalah para produsen dan konsumen lorjuk di Kabupaten Pamekasan. Adapun produsen yang dimaksud adalah para pencari lorjuk, para pengepul dan pengolah lorjuk serta penjual lorjuk, sedangkan konsumen adalah para pembeli dan pengkonsumsi lorjuk.

Adapun karakteristik responden adalah sebagai berikut:

1. Lokasi pencarian "lorjuk"

2. Umur produsen dan konsumen

3. Pendidikan produsen dan konsumen

Hasil dari penyebaran kuisioner yang diberikan ke 10 responden pencari lorjuk di masing-masing kecamatan Jika dilihat dari tempat pencarian "lorjuk" maka diperoleh 8 dari 10 pencari "lorjuk" mencari di dua wilayah kecamatan sedangkan 2 orang mencari hanya satu wilayah kecamatan saja dan bila berdasarkan jenis kelamin untuk para pencari lorjuk diperoleh hasil bahwa 20 responden $(100 \%)$ berjenis kelamin perempuan, pengepul dan pengolah "lorjuk" sebanyak 3 responden (100\%) semuanya berjenis kelamin perempuan.

Sedangkan usia responden pencari lorjuk diperoleh 8 orang berusia antara 50 tahun-65 tahun sedangkan 12 orang yang lain berusia 35 tahun -50 tahun. Usia para pengepul dan pengolah lorjuk adalah antara 50 tahun - 60 tahun. Sedangkan untuk penjual lorjuk usianya 45 tahun sampai 75 tahun. Usia konsumen dari 10 responden $4(40 \%)$ responden berusia antara 20 tahun sampai 35 tahun, responden yang berusia 35 tahun -50 tahun sejumlah $4(40 \%)$ responden, sedangkan yang berusia 50 tahun - 65 tahun sebanyak 2 (20\%) responden.

Tingkat pendidikan untuk para pencari, pengepul dan pengolah lorjuk 90\% hanya mencapai tingkat SMP , untuk para penjual lorjuk sampai tingkat SMA.

\section{Konsumen}

Untuk konsumen dari 10 responden, $7(70 \%)$ orang berjenis 
kelamin perempuan sedangkan 5 (30\%) orang laki-laki

Sedangkan tingkat pendidikan para konsumen dari 10 responden 2 (20\%) responden pendidikan akhirnya SMP, sedangkan $6(60 \%)$ responden sampai jenjang S1 dan 2 (20\%) responden pendidikan terakhirnya S2.

Tingkat pendapatan per bulan juga bisa diklasifikasikan sebagai karakteristik responden. Hasilnya menunjukkan bahwa sebagian besar tingkat pendapatan konsumen antara Rp. 1.000.000.00, - Rp. $5.000 .000,00$ sebanyak 10(100\%) responden. Adapun pekerjaan konsumen $8(80 \%)$ responden sebagai PNS dan 2 $(20 \%)$ responden sebagai wiraswasta atau pengusaha.

Hal ini mengidentifikasikan bahwa mayoritas para konsumen produk "lorjuk" adalah orang-orang yang memiliki pendapatan tetap dan berpenghasilan tinggi.

\section{Keragaan Usaha "Lorjuk"}

Kerang yang satu ini memang bentuknya sedikit berbeda dengan kerang kebanyakan. Ia memiliki cangkang yang beruas-ruas mirip seperti bambu. Dengan rasanya yang khas ia pun bisa dibuat menjadi beragam olahan.

Masyarakat Jawa Timur dan Madura, kerang bambu yang dikenal juga memiliki nama Razor clams ini dikenal dengan "lorjuk". Ia merupakan termasuk jenis kerang yang banyak terdapat di perairan atau pantai pesisir pulau Madura.

Kerang bambu ini berbentuk kecil panjang yang biasa hidup di pesisir pantai yang berlumpur. Biota yang termasuk ordo Veneroida ini memiliki cangkang berwarna kecoklatan. Bagian cangkang yang agak putih dilengkapi garis-garis coklat kehijauan, membuat biota ini sekilas mirip dengan bilah bamboo.

\section{Pendapatan Usaha “ Lorjuk"}

Lorjuk adalah sejenis kerang yang biasa hidup di pantai pasir ini, biasanya kalau digoreng berwarna kecoklatan, rasanya gurih. Menjelang hari Raya, lorjuk menjadi incaran ibu-ibu rumah tangga untuk disajikan sebagai hidangan. Lorjuk sangat disukai karena tidak saja rasanya gurih dan enak tetapi gizinya juga tinggi.

Lorjuk Goreng ini merupakan Camilan Khas Madura terbuat dari Lorjuk pilihan yang di ambil dari lautan, disamping rasanya yang enak, lezat, gurih, lorjuk goreng ini mempunyai kandungan gizi yang tinggi, sangat cocok buat camilan, lauk pauk, dan di campur dengan camilan lainnya seperti rengginang, kacang dan lain sebagainya.

Dari hasil kuisioner dan wawancara langsung dengan produsen dalam hal ini adalah pencari lorjuk, pengepul dan pengolah "lorjuk" diperoleh informasi bahwa permintaan "lorjuk" semakin meningkat. Tetapi produktifitasnya tidak 
menentu. Performen "lorjuk" sangat menarik bagi para konsumen. Produk "lorjuk" sangat diminati oleh konsumen karena rasanya yang gurih dan lezat. Namun demikian tidak mudah untuk mendapatkan produk ini, karena hanya terdapat didaerah tertentu saja. Pantai yang menjadi habitat "lorjuk" juga tidak terlalu banyak, demikian juga produktifitasnya. "Lorjuk" bersifat musiman sehingga jika tidak pada musimnya produksi "lorjuk" sangat sedikit. Pada proses pencarian membutuhkan keahlian tersendiri dan harus dengan menggali pasir dipantai. Proses pencariannyapun harus menunggu air laut dalam kondisi surut. Jika lama surut air laut hanya sebentar maka waktu pencarian "lorjukpun" juga sangat terbatas. Hal inilah yang menyebabkan harga "lorjuk" relative tinggi.

Produksi rata-rata "lorjuk" tiap hari antara 300gram - 500 gram. Hal ini juga disampaikan oleh para pengepul dan pengolah "lorjuk" pembeliannya rata-rata hanya mencapai $50 \mathrm{Kg}$ per bulan. Hal ini sangat kurang seimbang jika dibandingkan dengan permintaan pasar yang semakin meningkat.

Namun demikian tidak semua orang menyukai produk"lorjuk" ini tentunya dengan alasan yang berbedabeda. Begitupun stok produk"lorjuk" ditoko" biasanya cukup lama terjual. Hal ini menunjukkan bahwa produk "lorjuk" memang memiliki konsumen tersendiri.

Harga "lorjuk" kering yang dijual pengolah adalah Rp 200.000,00 sedangkan mereka membeli dari pencari lorjuk tiap 100 gram basah seharga sekitar Rp. 5000,00 , jika sudah kering maka berat lorjuk tersebut hanya 50 gram. Namun hal ini sudah memberikan keuntungan bagi pengolah lorjuk tersebut. Ditingkat penjual "lorjuk" goreng untuk satu kemasan yang bervariasi harganya antar Rp.20.000,00 sampai Rp. 30.000,00.

\section{Segmentasi "Lorjuk"}

Segmentasi "Lorjuk" dalam Sudut Pandang Produsen

Identifikasi segmentasi "lorjuk" dalam sudut pandang produsen diperoleh melalui analisis cluster terhadap atribut Dari hasil kuisioner dan wawancara langsung dengan produsen yaitu menunjukkan bahwa produsen (pengolah "lorjuk) mengirimkan hasil olahannya ke penjual ( toko camilan). Mereka tidak hanya menjual pada satu tempat saja tetapi juga langsung kepada konsumen. Biasanya para konsumen membeli dalam jumlah banyak dan digunakan sebagai oleh-oleh.

Banyaknya perusahaan yang melakukan segmentasi pasar atas dasar pengelompokkan variabel tertentu. Dengan menggolongkan atau mensegmentasikan pasar seperti itu, dapat dikatakan bahwa secara umum perusahaan mempunyai 
motivasi untuk mempertahankan dan meningkatkan tingkat penjualan dan yang lebih penting lagi agar operasi perusahaan dalam jangka panjang dapat berkelanjutan dan kompetitif (Porter, 1991).

Berikut adalah Tabel Segmentasi "Lorjuk" dari sudut pandang produsen

Tabel 1. Segmentasi "Lorjuk" dari Sudut Pandang Produsen

\begin{tabular}{|c|c|}
\hline Indikator & Keterangan \\
\hline \multicolumn{2}{|l|}{ Geografi } \\
\hline Tempat penjualan & $\begin{array}{l}\text {-Toko Camilan Madura } \\
\text {-Swalayan } \\
\text {-Toko kue }\end{array}$ \\
\hline Letak Toko & $\begin{array}{l}\text {-Dalam kota } \\
\text {-Dekat jalan utama } \\
\text {-Dekat tempat wisata }\end{array}$ \\
\hline \multicolumn{2}{|l|}{ Demografi } \\
\hline Usia & $\begin{array}{l}\text { Bisa mengetahui konsumen yang menyukai } \\
\text { lorjuk lebih didominasi oleh konsumen usia 20- } \\
50 \text { Tahun. }\end{array}$ \\
\hline Jenis kelamin & Laki-laki maupun perempuan menyukai lorjuk \\
\hline Pendidikan & SMU, diploma dan sarjana \\
\hline \multirow[t]{2}{*}{ Penghasilan } & $\begin{array}{l}\text { Bisa mengetahui segmen mana yang menyukai } \\
\text { produk lorjuk }\end{array}$ \\
\hline & $\begin{array}{l}\text { Bisa mengalokasikan anggaran untuk membuat } \\
\text { produk lorjuk yang lebih diminati konsumen }\end{array}$ \\
\hline \multirow[t]{3}{*}{ Perilaku Produsen } & Memilih lokasi penjualan untuk menjual lorjuk \\
\hline & $\begin{array}{l}\text { Bisa mengetahui respon dari para konsumen } \\
\text { lorjuk }\end{array}$ \\
\hline & Bisa mengetahui daya tarik konsumen lorjuk \\
\hline
\end{tabular}

Sumber: hasil dari pengolahan data

Dari Tabel 1 diatas menunjukkan bahwa segmentasi pasar sangat penting peranannya bagi produsen. Hal ini jelas sangat mempengaruhi pola pikir dan kreatifitas produsen lorjuk agar bisa meningkatkan kualitas dan menganekaragamkan produk lorjuk yang dihasilkan. Produsen lorjuk dalam hal ini adalah penjual bisa mengatur dimana dan siapa saja yang menjadi konsumen dari lorjuk yang dijual segmen mana yang dituju untuk menjual produknya. Penjual lorjuk menempatkan lorjuk pada etalasenya ditempat paling depan dan dapat langsung terlihat oleh konsumen. Hal ini dilakukan sebagai strategi agar konsumen langsung bisa melihat produk lorjuk dan tertarik untuk membalinya. Kemasan dibuat bagus dan menarik serta dengan ukuran yang sedang sehingga harganya tidak terlalu mahal dan masih terjangkau oleh konsumen. 
Manfaat segmentasi pasar yaitu manfaat yang lain dengan dilakukannya segmentasi

pasar,antaralain:

1. Perusahaan akan dapat mendeteksi secara dini dan tepat mengenai kecenderungan-kecenderungan dalam pasar yang senantiasa berubah.

2. Dapat mendesign produk yang benarbenar sesuai dengan permintaan pasar. 3. Dapat menentukan kampanye dan periklanan yang paling efektif.

4. Dapat mengarahkan dana promosi yang tersedia melalui media yang tepat bagi segmen yang diperkirakan akan

Tabel 2. Segmentasi "Lorjuk" dari

\section{Sudut Pandang Konsumen}

\begin{tabular}{|l|l|}
\hline Indikator & Keterangan \\
\hline Geografi & $\begin{array}{l}\text { Di Komplek Perumahan, } \\
\text { di kota,di desa,dalam } \\
\text { kota, luar kota }\end{array}$ \\
\hline Tempat tinggal & \\
\hline Demografi & $\begin{array}{l}\text { Rata-rata antara 20 Th- } \\
\text { 50 Th }\end{array}$ \\
\hline Usia & $\begin{array}{l}\text { Perempuan dan Laki- } \\
\text { laki }\end{array}$ \\
\hline Jenis Kelamin & $\begin{array}{l}\text { Mayoritas dari SMU } \\
\text { sampai sarjana }\end{array}$ \\
\hline Pendidikan & $\begin{array}{l}\text { Rata-rata Rp. } \\
\text { 1.000.000,00-Rp } \\
\text { 5.000.000,00 per bulan }\end{array}$ \\
\hline Penghasilan & $\begin{array}{l}\text { Guru, Dosen, } \\
\text { wiraswasta, } \\
\text { pengusaha,PNS,dll }\end{array}$ \\
\hline Profesi & $\begin{array}{l}\text {-Bisa diolah menjadi } \\
\text { berbagai olahan } \\
\text {-Makanan yang } \\
\text { menyehatkan }\end{array}$ \\
\hline $\begin{array}{l}\text { Perilaku } \\
\text { Konsumen }\end{array}$ & Manfaat
\end{tabular}

menghasilkan keuntungan yang lebih besar.

5. Dapat digunakan untuk mengukur usaha promosi sesuai dengan masa atau periodeperiode dimana reaksi pasar cukup besar.

Segmentasi "Lorjuk" dalam Sudut Pandang Konsumen

Berdasarkan hasil wawancara dan kuisioner diperoleh hasil bahwa sudut pandang konsumen menunjukkan "lorjuk" memiliki konsumen dari segmen tersendiri. Berikut adalah Tabel Segmentasi "Lorjuk" dari sudut pandang konsumen.

\begin{tabular}{|l|l|}
\hline & $\begin{array}{l}\text {-Kandungan proteinnya } \\
\text { tinggi }\end{array}$ \\
\hline Rasa & Enak dan gurih \\
\hline $\begin{array}{l}\text { Alasan } \\
\text { membeli }\end{array}$ & $\begin{array}{l}\text {-Untuk camilan } \\
\text {-Untuk suguhan dirumah } \\
\text {-Untuk oleh-oleh }\end{array}$ \\
\hline & \\
\hline $\begin{array}{l}\text { Tingkat } \\
\text { Pembelian }\end{array}$ & $\begin{array}{l}\text { Rata-rata lebih dari 1 } \\
\text { kali tiap bulan }\end{array}$ \\
\hline $\begin{array}{l}\text { Tingkat } \\
\text { Pemakaian }\end{array}$ & Cukup \\
\hline Daya Beli & Cukup tinggi \\
\hline $\begin{array}{l}\text { Sikap terhadap } \\
\text { Produk }\end{array}$ & $\begin{array}{l}\text { Respon positip dan } \\
\text { merupakan makanan } \\
\text { yang khas dari } \\
\text { Pamekasan }\end{array}$ \\
\hline Kemasan & Menarik dan praktis \\
\hline $\begin{array}{l}\text { Tempat } \\
\text { pembelian }\end{array}$ & $\begin{array}{l}\text { Mayoritas beli di Toko } \\
\text { Camilan Madura }\end{array}$ \\
\hline Psikografi & $\begin{array}{l}\text { Buat camilan dan oleh- } \\
\text { oleh }\end{array}$ \\
\hline Aktifitas & Cukup tinggi \\
\hline Minat & $\begin{array}{l}\text {-Menarik, enak dan } \\
\text { prestise } \\
\text {-Menyukai sea food }\end{array}$ \\
\hline Opini & \\
\hline Sumber: Hasil & pangolahan data \\
\hline
\end{tabular}

Sumber: Hasil dari pengolahan data 
Dari Tabel 2 diatas, hasil penelitian menunjukkan bahwa dari segi geografi diperoleh bahwa konsumen "lorjuk" berasal dari berbagai Komplek Perumahan, tinggal di kota, di desa, dari dalam kota Pamekasan sendiri dan dari luar kota yaitu Bangkalan, Sampang dan Sumenep.

Dari segi demografi untuk jenis kelamin menunjukkan konsumen "lorjuk" adalah perempuan dan laki-laki sama-sama menyukai lorjuk, dari segi usia adalah yang berusia produktif yaitu antara 20 tahun -50 tahun. Responden dipilih mulai usia 20 tahun dengan asumsi bahwa konsumen tersebut sudah bisa memiliki penghasilan sendiri. Tingkat pendidikan konsumen mulai dari SMU dan sederajat sampai tingkat sarjana. Sedangkan dari profesi konsumen "lorjuk" ini adalah guru, dosen, pengusaha, wiraswasta dan PNS. Konsumen tersebut rata-rata memiliki penghasilan yaitu antara 1 juta rupiah sampai 5 juta rupiah per bulan.

Dari segi perilaku konsumen menunjukkan bahwa mengkonsumsi "lorjuk" cukup memiliki manfaat yaitu sebagai sumber protein hewani. Sedangkan jumlah pembelian rata-rata konsumen yaitu antara 1-2 kali dalam satu bulan.Daya beli responden cukup baik karena mereka memiliki pendapatan yang cukup tinggi. Tempat pembelian produk "lorjuk" cukup mudah dan cepat diakses, sehingga konsumen tidak mengalami kesulitan dalam memperolehnya.

Berdasarkan psikografi untuk aktifitasnya biasanya digunakan utnuk camilan dan oleh-oleh, sedangkan minat konsumen terhadap lorjuk cukup tinggi. Untuk opini konsumen yaitu bahwa produk lorjuk ini menarik, enak dan merupakan camilan yang menunjukkan prestise seseorang serta gaya hidup yang tinggi selain itu konsumen menyukai sea food.

Berikut adalah hasil pengklasteran konsumen "lorjuk" seperti pada Tabel 3 dibawah ini : 
Tabel 3. Distribusi Variabel

\begin{tabular}{|l|l|l|l|l|}
\hline No & Nama Cluster & Jumlah Responden & Persentase & Variabel \\
\hline 1 & Cluster 1 & 10 & $33,3 \%$ & $\begin{array}{l}\text { Rasanya enak dan } \\
\text { gurih } \\
\text { Protein tinggi } \\
\text { Makanan sehat }\end{array}$ \\
\hline 2 & Cluster 2 & 7 & $23,3 \%$ & $\begin{array}{l}\text { Suka seafood } \\
\text { Prestise } \\
\text { Image yang bagus }\end{array}$ \\
\hline 3 & Cluster 3 & 13 & $43,3 \%$ & $\begin{array}{l}\text { Bisa buat camilan } \\
\text { Bisa buat oleh-oleh } \\
\text { Bisa buat suguhan } \\
\text { tamu }\end{array}$ \\
\hline
\end{tabular}

Sumber : Hasil dari pengolahan data

Pembahasan tentang cluster 1 menunjukkan bahwa responden yang memilih atribut rasa enak dan gurih, protein tinggi dan merupakan makanan sehat sebanyak 33,3\%, sedangkan yang memilih atribut suka seafood, prestise dan image yang bagus sebanyak 23,3\% dan yang memilih atribut bisa dibuat camilan,

\section{KESIMPULAN DAN SARAN}

\section{Kesimpulan}

Dari penelitian yang dilakukan diperoleh kesimpulan sebagai berikut:

1. Keragaan "lorjuk" masih di daerah Pamekasan masih memiliki potensi yang menjanjikan. Keberadaannya sangat diminati oleh konsumen, karena cita rasanya yang khas enak, gurih dan renyah. Selain itu "lorjuk" juga memiliki kandungan protein dibuat oleh-oleh dan di buat suguhan tamu sebanyak 43,3\%. Hal ini menunjukkan bahwa segmentasi pasar "lorjuk" untuk konsumen lebih didominasi karena alasan sebagai makanan camilan, untuk oleh-oleh dan untuk suguhan tamu dirumah yaitu sebesar $43,3 \%$.

yang tinggi sehingga merupakan salah satu pilihan makanan yang sehat.

2. Segmentasi "Lorjuk" dari Sudut

Pandang Produsen

\begin{tabular}{|l|l|}
\hline Indikator & Keterangan \\
\hline Geografi & \\
\hline $\begin{array}{l}\text { Tempat } \\
\text { penjualan }\end{array}$ & $\begin{array}{l}\text {-Toko Camilan } \\
\text { Madura } \\
\text {-Swalayan } \\
\text {-Toko kue }\end{array}$ \\
\hline Letak Toko & $\begin{array}{l}\text {-Dalam kota } \\
\text {-Dekat jalan utama } \\
\text {-Dekat tempat wisata }\end{array}$ \\
\hline Demografi & Bisa mengetahui \\
\hline Usia & \\
\hline
\end{tabular}




\begin{tabular}{|c|c|}
\hline & $\begin{array}{l}\text { konsumen yang } \\
\text { menyukai lorjuk } \\
\text { lebih didominasi } \\
\text { oleh konsumen usia } \\
\text { 20-50 Tahun. }\end{array}$ \\
\hline $\begin{array}{l}\text { Jenis } \\
\text { kelamin }\end{array}$ & $\begin{array}{l}\text { Laki-laki maupun } \\
\text { perempuan } \\
\text { menyukai lorjuk }\end{array}$ \\
\hline Pendidikan & $\begin{array}{l}\text { SMU, diploma dan } \\
\text { sarjana }\end{array}$ \\
\hline \multirow[t]{2}{*}{ Penghasilan } & $\begin{array}{l}\text { Bisa mengetahui } \\
\text { segmen mana yang } \\
\text { menyukai produk } \\
\text { lorjuk }\end{array}$ \\
\hline & $\begin{array}{l}\text { Bisa mengalokasikan } \\
\text { anggaran untuk } \\
\text { membuat produk } \\
\text { lorjuk yang lebih } \\
\text { diminati konsumen }\end{array}$ \\
\hline \multirow[t]{3}{*}{$\begin{array}{l}\text { Perilaku } \\
\text { Produsen }\end{array}$} & $\begin{array}{l}\text { Memilih lokasi } \\
\text { penjualan untuk } \\
\text { menjual lorjuk }\end{array}$ \\
\hline & $\begin{array}{l}\text { Bisa mengetahui } \\
\text { respon dari para } \\
\text { konsumen lorjuk }\end{array}$ \\
\hline & $\begin{array}{l}\text { Bisa mengetahui } \\
\text { daya tarik konsumen } \\
\text { lorjuk }\end{array}$ \\
\hline
\end{tabular}

3. Segmentasi "Lorjuk" dari Sudut Pandang Konsumen

\begin{tabular}{|l|l|}
\hline Indikator & Keterangan \\
\hline Geografi & $\begin{array}{l}\text { Di Komplek Perumahan, } \\
\text { di kota,di desa,dalam } \\
\text { kota, luar kota }\end{array}$ \\
\hline Tempat tinggal & $\begin{array}{l}\text { Rata-rata antara 20 Th- } \\
50 \text { Th }\end{array}$ \\
\hline Demografi & $\begin{array}{l}\text { Perempuan dan Laki- } \\
\text { laki }\end{array}$ \\
\hline Usia & $\begin{array}{l}\text { Mayoritas dari SMU } \\
\text { sampai sarjana }\end{array}$ \\
\hline Jenis Kelamin & $\begin{array}{l}\text { Rata-rata Rp. } \\
1.000 .000,00-R p \\
5.000 .000,00 \text { per bulan }\end{array}$ \\
\hline Pendidikan & Guru, Dosen, \\
\hline Penghasilan
\end{tabular}

\begin{tabular}{|c|c|}
\hline & $\begin{array}{l}\text { wiraswasta, } \\
\text { pengusaha,PNS, dll }\end{array}$ \\
\hline \multicolumn{2}{|l|}{$\begin{array}{l}\text { Perilaku } \\
\text { Konsumen }\end{array}$} \\
\hline Manfaat & $\begin{array}{l}\text {-Bisa diolah menjadi } \\
\text { berbagai olahan } \\
\text {-Makanan yang } \\
\text { menyehatkan } \\
\text {-Kandungan proteinnya } \\
\text { tinggi }\end{array}$ \\
\hline Rasa & Enak dan gurih \\
\hline $\begin{array}{l}\text { Alasan } \\
\text { membeli }\end{array}$ & $\begin{array}{l}\text {-Untuk camilan } \\
\text {-Untuk suguhan dirumah } \\
\text {-Untuk oleh-oleh }\end{array}$ \\
\hline $\begin{array}{l}\text { Tingkat } \\
\text { Pembelian }\end{array}$ & $\begin{array}{l}\text { Rata-rata lebih dari } 1 \\
\text { kali tiap bulan }\end{array}$ \\
\hline $\begin{array}{l}\text { Tingkat } \\
\text { Pemakaian }\end{array}$ & Cukup \\
\hline Daya Beli & Cukup tinggi \\
\hline $\begin{array}{l}\text { Sikap terhadap } \\
\text { Produk }\end{array}$ & $\begin{array}{l}\text { Respon positip dan } \\
\text { merupakan makanan } \\
\text { yang khas dari } \\
\text { Pamekasan }\end{array}$ \\
\hline Kemasan & Menarik dan praktis \\
\hline $\begin{array}{l}\text { Tempat } \\
\text { pembelian }\end{array}$ & $\begin{array}{l}\text { Mayoritas beli di Toko } \\
\text { Camilan Madura }\end{array}$ \\
\hline Psikografi & \\
\hline Aktifitas & $\begin{array}{l}\text { Buat camilan dan oleh- } \\
\text { oleh }\end{array}$ \\
\hline Minat & Cukup tinggi \\
\hline Opini & $\begin{array}{l}\text {-Menarik, enak dan } \\
\text { prestise } \\
\text {-Menyukai sea food }\end{array}$ \\
\hline
\end{tabular}

Sedangkan "lorjuk" menurut sudut pandang konsumen adalah bahwa "lorjuk" Pembahasan tentang cluster 1 menunjukkan bahwa responden yang memilih atribut rasa enak dan gurih, protein tinggi dan merupakan makanan sehat sebanyak 20\%, sedangkan yang memilih atribut suka seafood, prestise dan image yang 
bagus sebanyak $26 \%$ dan yang memilih atribut bisa dibuat camilan, dibuat oleh-oleh dan di buat suguhan tamu sebanyak 54\%. Hal ini menunjukkan bahwa segmentasi pasar "lorjuk" untuk konsumen lebih didominasi karena alasan sebagai makanan camilan, untuk oleh-oleh dan untuk suguhan tamu dirumah yaitu sebesar $54 \%$.

\section{Saran}

Perlu dilakukan penelitian lebih lanjut mengenai manajemen pemasaran yang mengaitkan berbagai aspek dan strategi pemasaran sehingga keunggulan bersaing dalam usaha "lorjuk" menjadi lebih sempurna.

\section{DAFTAR PUSTAKA}

Badan Busat Statistik. 2012. Kabupaten Pamekasan dalam Angka. Pamekasan

Direktorat Jenderal Pesisir dan PulauPulau Kecil. Departemen Kelautan dan Perikanan

2010. Survei Sensus

Ekonomi Nasional. Ditjen PPHP. Jakarta.

----------------, 2010. Menurunnya Konsumsi Siput/Kerang 2009. Warta Pasarikan, Edisi Maret 2010, Volume 79. Jakarta.

Bilson. S, 2004. Riset Pemasaran. Penerbit. Gramedia Pustaka Utama. Jakarta.

Cravens, D.W. 1997.Strategic Marketing, Richard D. Irwin,Inc.
Dahuri. R, Rais.J, Ginting.SP dan Sitepu. 2001. Pengelolaan Sumber Daya Wilayah Pesisir dan Lautan Secara Terpadu. PT. Pradnya Paramita. Jakarta

Damaijati.E. 2003. Metodologi Pemilihan Agribisnis. Penerbit. UPN Press. Surabaya.

Dewi.H dan Syafrizal, 2008. Analisis Segmentasi, Targeting dan positioning Program Pendidikan Magister (Studi pada Institusi Penyelenggara MM di Kota Padang). Vol. 13 No. 2 Padang.

Istri. A, 2010. Analisis Strategi Segmentasi, Targeting dan Positioning "Kacang Manis mentari" (UD. Murni Asih) di Kota Denpasar. Denpasar

Kotler Philip. 1997. Marketing Manajemen : Analysis, Planning, Implementation and Control, Jilid 1, Nineth edition, New Jersey : Prentice Hall International.

Kuncoro. D, 2003. Metode Riset untuk Bisnis dan Ekonomi. Penerbit. Erlangga. Jakarta.

Kusnadi, 2007. Jaminan Sosial Nelayan. Penerbit. LKIS. Yogyakarta.

Kotler \& Gary Amstrong, 2001, Prinsip Prinsip Pemasaran. Jilid 1. Edisi ke Delapan, Penerbit Erlangga, Jakarta.

Michael E.Porter,.1997. Strategi Bersaing. Teknik Menganalisis Industri Dan Pesaing. Alih Bahasa, Agus Maulana. Penerbit Erlangga, Jakarta

Michael E.Porter,.1994. Keunggulan Bersaing. Menciptakan dan Mempertahankan Kinerja Unggul. Penerbit Binarupa Aksara, Jakarta. 
Nontji.A, 2005. Laut Nusantara. Penerbit Djambatan. Jakarta.

Said.G dan Intan. H, 2001. Manajemen Agribisnis. Penerbit Ghalia Indonesia. Jakarta.

Saragih. B, . 2000, Jurnal Studi Pembangunan, Kemasyarakatan dan Lingkungan Agribisnis sebagai landasan Pembangunan Ekonomi Indonesia dalam era milenium baru, makalah Pengantar Seminar Mengenai Prospek Sosial Ekonomi
Indonesia tahun 2000, 04 Pebruari 2000, Bandung.

Sarwono. J, 2006. Metode Penelitian Kuantitatif dan Kualitatif. Penerbit. Graha Ilmu. Yogyakarta.

Soekartawi, 2005. Agribisnis. Penerbit PT. Raja Grafindo Persada. Jakarta.

Swastha.B, 2002. Asas- Asas Marketing, Edisi Ketiga, Yogyakarta 